Original Article

\title{
The Spiritual Approach to Systemic Family Therapies
}

\author{
Hasan Kütük ${ }^{1(10)}$ \\ Ph.D. Candidate
}

${ }^{1}$ Ph.D. Candidate, Marmara University, İstanbul, 34722, Turkey. E-mail: hasankutuk28@gmail.com

\section{Corresponding author: \\ Hasan Kütük}

\section{E-mail:}

hasankutuk28@gmail.com

eISSN: $2458-9675$

Received Revision:

18.11.2019

Revision:

03.01.2020

Accepted:

13.02.2020

CC Copyright 2020

by Author(s)

\begin{abstract}
The concept of spirituality has started being included in therapy settings due to the new paradigms showing developments in the world of psychology in the late 20th century and in the 21st century. When examining the literature, many articles and books are seen to have been published related to the topic, and most of the studies have been carried out abroad. These performed studies have contributed new concepts and information to the literature by revealing how the concept of spirituality can be integrated with family therapies. This study has been prepared for the purposes of drawing the attention of researchers who conduct studies in Turkey based on systemic family therapy and of specialists who plan therapy sessions based the relevant theory to the topic and to provide the literature with a topic that finds no examples in the literature of Turkey. How the concept of spirituality can be used in harmony with the systemic family therapy approach and what the techniques of the spirituality-based systemic family therapy are have been prepared by being based on the many studies that have been published abroad. Before beginning the study, theoretical information and basic concepts primarily about systemic family therapies are provided, and then it moves on to spirituality-oriented systemic family therapy by briefly mentioning the concept of spirituality. How the concept of spirituality can be applied to systemic family therapy and the points and ethical situations to which counselors need to pay attention are also mentioned. Lastly, sample cases are shared by providing information about the techniques of using religious stories and spiritual dialogue, these techniques being used in spirituality-oriented systemic family therapies.
\end{abstract}

Keywords: Systemic family therapy $\bullet$ Spirituality $\bullet$ Family counseling $\bullet$ Religious stories usage $\bullet$ Spiritual dialogue

\section{Sistemik Aile Terapileri 'ne Manevi Yaklaşım}

$\ddot{O} z$

Yirminci yüzyılın sonlarında ve yirmi birinci yüzyılda psikoloji dünyasında gelişme gösteren yeni paradigmalar sayesinde maneviyat kavramı terapi ortamlarına dahil edilmeye bașlamıștır. Alan yazın incelendiğinde yapılan çalışmaların çoğunlukla yurtdışında gerçekleştirildiği ve konuyla ilgili birçok makale ve kitap yayınlandığı görülmektedir. Yapılan bu çalışmalar sayesinde maneviyat kavramının aile terapilerine nasıl entegre edilebileceği ortaya konularak, yeni kavram ve bilgilerle literatüre katkı sağlanmıştır. Bu çalışma ülkemizde sistemik aile terapisi kuramına dayalı çalışmalar yapan araștırmacıların ya da ilgili kurama dayalı olarak terapi seanslarını planlayan uzmanların ilgilerinin konuya çekilmesi ve ülkemiz alan yazınında örnekleri bulunmayan bir konuyu literatüre kazandırmak amacıyla hazırlanmıștır. Maneviyat kavramının sistemik aile terapisi yaklașımına uygun olarak nasıl kullanılabileceği ve manevi yaklaşımlı sistemik aile terapisi tekniklerinin neler olduğu yurt dışında yayınlanmış pek çok çalışma temel alınarak hazırlanmıştır. Çalışmadan öncelikle sistemik aile terapileri hakkında kuramsal bilgiler ve temel kavramlar verilmiş, daha sonra maneviyat kavramından kısaca bahsedilerek manevi yönelimli sistemik aile terapisine geçilmiştir. Sistemik aile terapisine maneviyat kavramının nasıl uyarlanabileceği, danıșmanların dikkat etmeleri gereken noktalar ve etik durumlara değinilmiştir. Son manevi yönelimli sistemik aile terapilerinde kullanılan "Dini Hikayelerin Kullanımı" ve "Manevi Diyalog” tekniklerin hakkında bilgi verilerek örnek vakalar paylaşılmıştır.

Anahtar Kelimeler: Sistemik Aile Terapisi • Maneviyat • Aile Danışmanlığı • Dini Hikâyelerin Kullanımı • Manevi Diyalog

Citation: Kütük, H. (2020). The spiritual approach to systemic family therapies. Spiritual Psychology and Counseling, 5, 25 - 43. https://dx.doi.org/10.37898/spc.2020.5.1.100 


\section{Systemic Family Therapy}

The first studies related to systemic family therapy began to appear in the 1950s. The systemic family therapy studies that were put forth, which began with the study by Gregory Bateson, Don D. Jackson, Jay Haley, and John Weakland (1956) on the communication patterns of schizophrenic patients, gained speed with the psychotherapy studies that Carl Whitaker did with schizophrenic patients and their families. Whitaker, who reached the conviction as a result of his studies that a healthy family continues to grow and develop despite almost all the types of problems that they can encounter, put forth that the family consists of processes that operate systematically. Bowen, another researcher who did studies with schizophrenic patients, mentioned the need for family members to individualize in order to protect mental health. Ackerman referred to the importance of sociality upon mental health in the studies he did with families that had different problems. As a result of the therapy processes he did with children, he detected the parents or other family members of the children who had recovered to show various neurotic symptoms. Researchers who had carried out studies on family systems, such as Virginia Satir, Salvador Minuchin, Jay Haley, and Cloe Madanes, brought new perspectives to family therapies by also developing their own models. Together with this, Gianfranco Cecchin, SelviniPalazzoli, Guliana Prata, and Luigi Boscolo, who labeled themselves as the Milan Group, focused on the concept of balance within the family by introducing the concepts of paradox and counterparadox (Dallos \& Draper, 2010).

Issues addressed in the systemic approach, such as unexpected losses and traumatic experiences, difficulties experienced in the internal communications of the family, or sensitive points related to the care of parents can be assessed among the main issues studied (Mert, 2014). According to the systemic approach, the most significant factors forming the system are the interactions and communications of the parts with one another. Isolations that may occur among the parts can lead to problems that deeply affect the system. Thus in systemic family therapy, the process gains functionality through the whole family being together. Meeting and looking for solutions with a family where the father is not included is not considered very meaningful in this respect (Nichols \& Schwartz, 2004).

In systemic family therapies, a state of wellness that will occur in other family members is caused by all family members supporting each other within the process. The active participation in the consultation process of all family members located within the family system will positively affect the system. According to systemic family therapists, planning sessions where the whole family is together is very important in terms of determining the family's internal communication patterns and being able to establish interactive relationships. During these sessions, the people who are seen by family members as problematic and who are claimed to disrupt the 
balance of the system are observed to not be treated with enough flexibility; conflicts and resistances exist in the relationships. The state of balance and awareness that will be created among the family members' communication patterns allows the entire system to stay on its feet (Kesici, Bayrakc1, Mert, \& Kiper, 2013).

Systemic theory aims to create flexibility in behaviors and increase the number of acceptable behaviors within the consultation process. Every family is a unique system. Therefore, the intervention methods that can be performed with families also vary. A method that is functional in family can feed problems even more in another family. Therefore, the competence of the advisor applying the systemic family therapy additionally has importance. The advisor should support the family in determining and changing the dysfunctional behavior patterns in the family. While doing this, the advisor should refrain from assigning tasks in a style that will directly interfere with this process. The advisor's job is to raise awareness among family members. Family members should decide together which steps will be thrown out. The basis of the systemic approach lies in discovering the connections that cause the problem and detecting blockages within the system rather than directly eliminating what has been identified (Özabacı \& Erkan, 2013).

The new schools that have emerged as postmodern approaches focus on individual differences. Each individual having a unique story is argued to come forth from the selfformations of a living system (Nichols \& Schwartz, 2004). Alongside psychotherapy schools' tendency toward postmodern approaches in the late 20th century, systemic family therapy researchers sped up their research on ruptures in emotional bonds and social family systems. In this way, the focus of therapies is directed at the family members and social circle that have relations with the client rather than the client. People have been suggested to be influenced by the systems that are formed in the context of their social environment and by culture they live in (Krause, 2002).

Family systems theory is also essentially addressed as an emotional systems theory. This is because the theory is based on an understanding that suggests the need for understanding the emotional ties of the family that are experienced throughout their lives and to attempt to detect emotional distortions (Bowen, 1978). Family members are connected to one another psychologically throughout life, even if they experience separations during periods of their life. A healthy family system is formed when these members provide balance on the issue of being independent as well as dependent on one another and are able to control their emotions (Walsh \& Harrigan, 2003).

Developing different perspectives on the current problem is important in the systemic approach. Instead of looking at events from within a cause-and-effect relationship, developing different perspectives protects both the client as well as the other individuals who have a relationship with the client from seeing themselves as 
the source of the problem and from feeling ashamed. Restructuring the problem in more logical ways prepares the groundwork for recovery by trying to understand the impact of the problem on the client and the client's surroundings instead of getting to the root of the problem (Hedges, 2005).

The systemic approach's greatest contribution to the field of psychotherapy is its focus on family and friend systems the client interacts with rather than focusing on the client as the source of the problem. This case plays a developmental role in cooperation in the therapeutic relationship by protecting clients from seeing and accusing themselves as the root of the problem. According to this approach, success can be provided in therapy by changing the structure of the relationship one has with family members. Where the defects experienced in family relationship lie is emphasized in the source of child clients' problems. Therefore, the family is addressed as a whole and family experiences are worked on. Almost every behavior is believed to have a function within the family system. Emphasis is placed on which points are nurtured in the family and which things cause distortions while addressing the problem. For this reason, the family is addressed as a whole by planning efforts directed at the whole family in the therapeutic process (Dallos \& Draper, 2010).

\section{The Basic Concepts of Systemic Family Therapy}

\section{Impartiality}

As in most psychotherapy theories, impartiality has an important place in systemic family therapy. When family members receiving therapeutic help end the therapy, the therapist not making an impression about taking sides is very important in the context of systemic family therapy. The therapist needs to approach events objectively and conduct the process in this manner. The assumption exists at the base of this concept that each individual found within the family system will do the best they can at hand. A high level of communication should be established between the therapist and all family members (Hedges, 2005; Storms, 2011).

\section{Wholeness}

The concept of the system is a structure that emerges with many of the concepts coming together that are related to each other. Any changes that will occur in the structures found within the system also affect the system as a whole. Almost every system cannot be explained without examining the sub factors that form its self. The concept of family is also addressed as a system that the family members form by coming together. This system forms a whole that functions differently than the individuals who form it themselves. The concept of integrity in systemic family therapy is formed by combining almost all the types of relationships that can be addressed among family 
members. The behaviors of each family member are connected to the other family members' behaviors, and the family system works through the affect of these behaviors (Dallos \& Draper, 2010; Goldenberg \& Goldenberg, 1991; Hedges, 2005).

\section{Feedback}

Systems work attempt to maintain their existence by preserving their current balances. Feedback works with the aim of preserving this existing balance. Systems are constantly in flux for the purpose of achieving specific goals and not being affected by the events occurring within the family. Specific goals are set for this change, and feedback is considered necessary for the purpose of achieving them. The obtained feedback assists the current system on the issue of whether or not to re-include the previously experienced situations in the system. A cyclical process operates between the past experiences and their results in order to be able to understand the functionality of the system. This cycle works in order for the required information to be changed, corrected, and re-included in the system. The system maintains or changes the existing balance by reviewing the negative or positive feedback at the end point. While negative feedback allows the system to preserve its balance, positive feedback prevents transitioning to the previous order by forcing change in the system. The experiences, social relationships, and rituals within the family form and continue due to the feedback. Focusing on the process of change among family members instead of focusing on how the events that happened in the family laid the groundwork for other events is used as a more effective method in the therapeutic process (Dallos \& Draper, 2010; Goldenberg \& Goldenberg, 1991; Hedges, 2005).

\section{Life Cycle Stages}

Families go through many foreseeable and unpredictable stages throughout their lives. Events such as divorce, remarriage, starting a new job, retirement, death, and children leaving home can be given as examples of these stages. The family system may require an adjustment process in order to be able to adapt to these experienced life stages. This process may occur suddenly or may take place slowly and gradually depending on the stage. The crises experienced in these periods can damage the relationships among family members by harming the family system. Family therapists consider a glitch exists that emerges in these kinds of life stages based on many of the family members' problematic behaviors (Dallos \& Draper, 2010; Goldenberg \& Goldenberg, 1991).

\section{Rules}

Almost all systems are shaped within the framework of certain rules. Families are also systems that function according to specific rules. Each member learns what 
is and is not expected of them based on their experiences within the family. Certain rules are formed within the family system as a result of these learned behaviors and interactions. Repetitive cycles begin to form among family members through these rules. Communication patterns within the family can also be determined by revealing these rules and patterns. Instead of the needs within the family or the members' personality traits, these rules began to be effective. These rules can differ with respect to member's age, gender, or parentage. These rules that emerge within the family allow the system to maintain its balance by determining the family's boundaries. The functioning of the system can be differentiated by changing these rules at different life stages. Family therapists focus on the rules that generally upset the system and negatively affect family members. Interviews take place for the purposes of becoming aware of the emotions that these rules cause and having the rules become beneficial by restructuring them. The aim for new solutions is to create a new balance in the system by bending or reorganizing the old rules that caused harm (Goldenberg \& Goldenberg, 1991; Minuchin, 1974).

\section{Sub-Systems and Boundaries}

Systems may also be classified as open and closed systems. In open systems, information flow is in the form that will be both from outside to within the system and from inside the system outward. It contains no strict rules. Closed systems can be defined as more unproductive systems with strict rules and no information flow. The family system must be predisposed to working as an open system in order to work functionally. Family members' awareness increases toward information from outside due to the system being open. Adaptation skills develop. Closed systems don't allow change by keeping the systems of pathological families in balance. Problems cyclically and constantly repeat in families possessing this type of system. Adaptation cannot be provided and awareness does not develop in relation to the problems (Dallos \& Draper, 2010).

The concept of boundaries is the lines that separate the system and sub-systems from the outer world, such as the rules for communication and interactions within the family. Boundaries decide what will stay out of the system and what is included in the system by preserving the integrity of the family system. Limits prevent one sub-system from being included in another while at the same time allowing them to be separated from one another (Goldenberg \& Goldenberg, 1991; Minuchin et al., 1978).

Families are a large meta-system that host many sub-systems. The systems that have continuity within the family and include constant change and development are the parent, sibling, and spouse systems. Among these systems, the sub-system that most effects the family system is the spouse sub-system. A victim can be chosen from the other sub-systems in the disorders that may occur in this sub-system, and 
the problem can be debated over the victim. For example, the child sub-system is a beautiful example of this. Generally the problems between spouses affect the children, troubles show up behaviorally in the affected child, and the family begins to seek help in connection with this. Or, children can be forced to choose a side in a conflict between parents, or in simplest terms, the children are exposed to manipulations. The relationship model developed between parents is a role model to the children regarding male-female relations and can cause the children to repeat the same mistakes in their future lives (Goldenberg \& Goldenberg, 1991).

The sibling sub-system is a significant system in terms of children being able to socialize. Due to this system, children get their first ideas about what togetherness, agreement, competition, support, and social ties are. The first things learned in this system also impact the other systems that children will encounter in life, from school life to work life and social relations. The parent sub-system is important in terms of providing for, raising, and feeding children and allowing them to adapt to the values of the culture in which they live. Children learn the concept of authority and concepts such as decision-making skills, management, and possessing power thanks to their parents. A problem that forms in this system may be the main cause of a pathology that passes from generation to generation. Children who internalize a problematic behavior by observing it from the mother or father chronically continues the problematic behavior because they will raise children with the same rules when becoming a parent (Goldenberg \& Goldenberg, 1991).

\section{Cybernetics}

The concept of cybernetics constitutes one of the fundamental assumptions of the systemic approach. Systemic therapy has occurred and developed due to cybernetics. Thanks to cybernetics, therapists focus on the relationships clients have with those around them instead of on their inner world and produce solutions to these people's problems. Illuminating problematic schisms in communication by detecting repetitive communication patterns prepares the groundwork for the solution. According to systemic therapy, individuals affect and are affected by one another. The concept of cybernetics was developed by Norbert Weiner for the purpose of explaining how this interaction is organized between systems. According to Weiner, the body translates and uses feedback by processing the information that comes from the outside in order to be able to create balance. People produce new meanings as long as they are in communication with one another. When they enter into wrong relationships, misunderstandings emerge and disruptions occur in the system (Goldenberg \& Goldenberg, 1991; Hedges, 2005). Thanks to cybernetics and feedback, systemic family therapists tend to ask questions instead of techniques such as summarizing and interpreting. By asking the right questions, therapists attempt to learn the client's 
feelings, thoughts, and behaviors and have their clients find the mistakes on these points. Clients' communication systems are learned due to the questions. Solutions to the clients' problems are produced by detecting the schism points in communication as mentioned above (Hedges, 2005).

\section{Structuring Sessions in Systemic Family Therapies}

Systemic family therapies are a process that attempts discovery by looking for the source of the problem and stressor. It attempts to eliminate the problem by arriving at its source rather than using techniques. While structuring the process, the current problems, troubles, and relationships with people important in the client's life are focused on instead of the client's inner world. Due to functioning of the system and sub-systems being based on each other, a problem that emerges in any system or subsystem will also affect the others. The first stage of the therapy attempts to discover this point creating dysfunction within the family. The next step focuses on the interventions that are able to eliminate this dysfunction. Dallos and Draper (2010) explained the first stages of systemic therapy under four headings:

Looking for the sources of the problem. Problems within family systems emerge from communication problems or individuals' own internal problems. This problem can also work as a variable that forces and endangers the system, such as being able to prepare the groundwork for ensuring balance within the system. Individuals within the family can cause the continuity of the problem through their thoughts, behaviors, and assumptions. Therefore the entry to structuring the sessions can be done within the therapy by focusing on subsystems or working upon the individual.

Finding the solution paths. Some solution paths manufactured as solutions to the problem can prepare the groundwork for different problems to appear within the system. In such a situation, discovering the existing problems should be enabled, solutions developed for dealing with this problem should be talked about, and what kind of troubles in the system the solution will be able to open the path to should be discussed. The configuration performed at this point also resembles the functional analysis section that takes place in the cognitive behavioral therapy approach. The configuration begins by first examining when the problem started, how was it noticed, and by whom. The malfunctions that the problem causes should be determined. In order to be able to find the solution to this problem, discussions should be had about what is produced, what the feelings and thoughts about the problem are, and which of the produced solution paths are functional.

Forming the hypotheses. Hypotheses work as a basic starting point on the topics of where to start the therapy from and how the process will continue based on the problem the family is experiencing. Hypotheses may change as the information obtained about the family system increases. By means of the acquired information, 
new hypotheses are formed in place of the old ones. Because both the therapist and the family are active within the process, the hypotheses have a structure that nurtures the therapeutic relationship.

Exploring the meanings the individuals within the family system attribute to one another. This stage is conducted by examining the basic mindset of the family and the family members' views on the other members' behaviors. This stage focuses on the communication patterns, emotional affinities, and ways of thinking among family members.

\section{Spirituality}

Spirituality, being as old as human history, has been a part of individual experiences even when we look at the first remnants of human history and is a concept that maintains its impact at almost every level of life. This concept, which is seen as a part of individuals' inner worlds, at the same time possesses a structure that also has external reflections and impacts the individual in every aspect. Traces of spirituality can be encountered in existential questions about why humans were created or about the meaning of life (Pargament, 2002).

When examining the literature on what this concept is that holds an important place in our daily life, no clear definition is observed to have been made. The reason for this may be that spirituality and religion mainly have a unique structure in the individual's inner world. Spirituality is a significant sensation that is specific to the individual. While for some people this feeling is a part of the religion in which they believe, for others it is a transcendent experience that doesn't originate from any religion or religious practice (Polanski, 2003).

The concept of spirituality in English sources carries a meaning that is associated with the soul. That which is beyond the five senses and that which is incorporeal are used in its meanings. The Turkish Language Association (TDK, 2019) has definitions such as "intangible incorporeal things" and "strength of heart, morals."

According to TDK (2019), the concept of religion, which is used as a term in connection with spirituality, can be defined as "the universal phenomenon belonging to a group of sacred practices and rituals that is born due to beliefs in visible and invisible supernatural forces, objects, or beings." Sacredness is the thing that forms the common point of definitions related to spirituality. At the center of the sacred lays the concepts of God, divine power, or transcendental reality. A quest on reaching what is sacred is the central function that spirituality essentially intends (Pargament, 2007).

Spirituality is a concept that can be formed without religion. Although some people reject religion, they may tend to define themselves as having a spiritual personality. 
Even when rejecting religion, individuals are in fact on a sacred quest. This quest plays an important role in people's lives. Although the concepts of religion and spirituality are used separately, they are basically very close concepts to one another. The concept of spirituality is a phenomenon that, just as it largely overlaps with religion, can also exist without religion. For this reason, instead of dealing with religiousness and spirituality separately, the following sections will use the concept of spirituality, which covers each of the two (D'Souza \& Rodrigo, 2004; Pargament, 2007).

In the most general sense, spirituality means being connected to what is sacred or the desire to feel close to it. According to Worthinton and Aten (2009), four types of spirituality can be mentioned: Religious spirituality is the sense of devotion to the sacred presence that religious societies have determined. Humanist spirituality is the belief in the sacredness of humanity. Generally it is feeling close to a group of people and the state of making sacrifices for them. Nature spirituality is defined as believing in the sacredness of nature and having the tendency to establish connections with it. The feelings of astonishment that are experienced in the face of natural events or the feelings of admiration felt by one being affected by an exquisite view can be given as examples. Universal spirituality is the feelings related to creation. It consists of the thoughts that are on the topic of humans' search for their place in the universe, the struggle for self-discovery within the endlessness of the universe, or the splendor of the universe (Worthinton \& Aten, 2009).

While helping people in terms of allowing them to be able to make sense of the difficulties they experience, spirituality at the same time also improves coping skills. In Pargament's studies (as cited in Horozcu, 2010), spirituality is seen to have a healing role in struggling with coping skills and general health problems. Humans use spirituality as a buffer in the difficulties they face and in the stressful events they experience. In this way, the effects of problems decrease and spirituality plays a protective role. Spirituality is seen to be used as a force for coping in difficult periods of life such as the despair that can be experienced as a result of the meaning of life, its purposes, and experienced events. Individuals with high levels of spiritual characteristics are known to try to solve problems by means of their problem-solving skills and searching for social support (Krook, 2008).

\section{Systemic Family Therapy and Spirituality}

Adapting the concept of spirituality to the therapeutic setting is based on a holistic perspective. According to Frame (2003), spirituality is an internal resource that includes the individual's beliefs, values, awareness, and subjectivity. Cognitive, emotional, behavioral, and relational functioning is affected by spirituality. A complex relationship is assumed to exist among body, soul, and mind where physical, mental, 
and relational health are concerned. Americans, $90 \%$ of whom define themselves as highly religious or spiritual individuals, believe the topic of spirituality is a concept that needs to be addressed within therapy (Frame, 2003; Walsh, 2009).

While working with clients who see spirituality as an important value in their own lives, taking this person's situation into consideration and conforming to the language used and the client's spiritual nature may be necessary. Together with the increasing their awareness in the field of spirituality, therapists have developed their ability to display an effective approach to clients on these issues. A therapist may be expected to pay attention to the client's spiritual point of view and show respect despite not adopting the use of the concept of spirituality in the therapy. This attention nourishes the therapeutic relationship by preventing the client's problems from being ignored and underestimated or undermining their religious or spiritual views (Sperry \& Mansager, 2007).

A study done by Carlson, Fitzpatrick, Hecker, and Killmer (2002) expressed that two out of three people who've received training as a marriage/family therapist have stated spirituality to be a concept that needs to be included in the process of the therapeutic relationship. When compared to previously performed studies, this case is considered as a serious increase on the topic of including spirituality in the treatment process in the field of psychotherapy. Additionally, the vast majority of therapists have been determined to define themselves as having a spiritual personality. These therapists stated a strong relationship to exist between the concept of spirituality and mental health.

In the literature on psychology, the answer to two basic questions has been sought for the sake of understanding the relationship between spirituality and psychology. The first question is about if psychology and spirituality have independent structures from each other or, if not, do the concepts basically serve the same purpose; the second questions is about which one should be given priority in the therapy process. Five different models were developed by Sperry and Mansager (2007) on this relationship; these models summarize the views of the academic community on the issue.

According to the first relational model, spirituality and psychology are basically the same in the process of individual development, but psychology is one step ahead. Spiritual development is assessed within psychological development. As a result of a successful therapy process, individuals feel better and completed. Their spirituality is also impacted and improved by this holistic development. The psychoanalytic approach can be given as an example of this model.

In the second relational model, spirituality and psychology are basically the same in the individual's development, but spirituality is one step ahead. Psychological development is assessed within spiritual development. If the individual develops spiritually, the dominant view is that one's psychological development will be affected and improved by this. Those who adopt the pastoral counseling approach 
can be given as an example of this model, which is not considered so valid by the world of science.

With respect to the third relational model, even if spirituality and psychology sometimes overlap in the individual's developmental process, they have fundamentally different structures from one another. The psychological field has priority within the process. From time to time developments in the fields of psychology and spirituality may run parallel to each other. A change that can occur in either the spiritual field or the psychological field may affect the other even if they are different from one another. In this relational model, spiritual development advances based on psychological development. In other words, for a client to be able to benefit from a spiritually oriented psychological counseling process, they must reach a sufficient level of psychological maturity. Humanistic psychotherapy or the existentialist approach can be given as examples of this relational model.

With respect to the fourth relational model, spirituality and psychology are fundamentally different from one another even if they sometimes overlap each other in the process of individual development. Spiritual development is given priority in the process. The two can affect each other in the development process, but spiritual development is not a process that advances due to psychological development. Transpersonal psychology and theistic therapies can be given as examples of this approach.

The fifth relational model makes its interpretation from a holistic perspective. According to this model, psychology and spirituality are development processes that run separately from one another. One has no effect on the other, nor do they possess a primary impact on each other. Which area has priority during the therapy process should be determined according to the client's needs. Spirituality being primarily used would be more suitable if the story the client brings contains problems such as transcendental struggles, internal dialogues, the search for meaning, and answers to the basic questions of life. The use of spiritually oriented intervention techniques has greater priority for this client. However, the primary use of the psychological field would be more appropriate if the story the client brings covers problem such as worries, personality problems, or psychological depression. Using psychotherapyoriented interventions has priority in determining strategies suitable to the problem.

In the psychological counseling and psychotherapy literature, therapists are seen to approach spirituality as taboo and to not address it in therapy sessions, even though the importance of spirituality has been documented with research (Walsh, 2009). Research done in the 21 st century has shown awareness toward spirituality in the world of psychotherapy to have risen in recent years. When examining the literature, many articles and books are found on this subject in both individual and 
family counseling practices (Aponte, 2002; Carlson \& Erickson, 2009; Coffey, 2002; Hodge, 2005; Hoogestraat \& Trammel, 2003; Marterella \& Brock, 2008; Moules, 2000; Nedumaruthumchalil, 2009; Prest \& Keller, 1993; Walsh, 2009; Yeo Jin, \& Miller, 2010). Many family therapists consider discovering spiritual aspects to have significant value in the therapeutic relationship.

The concept of family is a structure that many religious systems view as important. When looking at the large religious communities accepted around the world, family life is seen to be given great importance. When looking at the teachings of religions such as Islam, Christianity, Judaism, and Hinduism, the importance of the family is seen to be emphasized (Griffith \& Rotter, 1999). Spirituality has recently gained importance in therapy approaches involved with families. Previously, therapists were thought to prefer staying away from issues like spirituality and religion due to the effect of the positivist paradigm. At the end of the 20th century and in the first years of the 21 st, family therapists began to integrate spirituality into therapies by keeping up with the changing scientific paradigm (Bentheim, 2005; Helmeke \& Bischof, 2007).

Therapists who started using spirituality in family therapies were particularly interested in topics such as intra-marital roles, forgiveness from the parties in the marriage, caring for elderly parents, and coping with children's problems. Directly impacting the problems specified under the therapists focus on these issues lay the family system's religious and spiritual orientations. Differences between couples related to spirituality and belief are able to cause conflicts, and family therapies are actively used in order to overcome this. Families who come to therapy enter the sessions complaining about a wide variety of problems. A competent spiritually oriented therapist should open the door to reflective dialogue on the family's spiritual orientations by noticing the points that are clogged within the family system. Having family members be more productive when determining alternative behaviors can be enabled by increasing family members' awareness in this way. When the therapy environment is appropriate to the couple's beliefs and values, they become more accepting and active by feeling more comfortable, and this has positive consequences in the therapy (Duba \& Watts, 2009).

The main question in spiritually oriented family therapy is the therapist's own spiritual orientation and the family system's views on spirituality. To be able to perform spiritually oriented family therapy, therapists need to possess specific criteria related to their own spiritual world. The points that spirituality touches and are considered important should be determined within the family system and in the subsystems that will be studied after providing this. In this way, the therapist obtains important data for the therapeutic process by discovering the sensitive points in the client's internal experience (Swington, 2001). 
By studying the topic of spirituality, systemic family therapists draw a road map in accordance with how clients identify themselves on the issue of spirituality. The client is given the decision about whether or not to include the concept of spirituality in accordance with their views on it. Discovering clients' spiritual aspects in the relational context facilitates the work of many therapists. The significant relationships established with individuals in the family system, with friends in the social circle, or with spiritual communities supply importance in terms of understanding the client's coping strategies or discovering their distorted thoughts. The use of spirituality in dealing with difficulties or the use of relationships established in the spiritual environment indicates the beneficial aspect of using these concepts in the therapy. Taking about these relationships within the therapy process works as a good resource for the therapist as this will speed up recovery (Kerr \& Bowen, 1998).

\section{Spiritually Oriented Systemic Family Therapy}

\section{Benefitting from Religious Stories}

Discovering the effects of the current family system and subsystems on their understanding of life is important in systemic family therapy. When clients learn how the system functions, where the points are that clog the system, and which points need to be changed for regulating the system, the most important problem in front of recovery means overcoming. Practices that are incompatible with the culture one lives in compared to the culture one grew up with, observed especially in immigrants, pressures within the family system, and social expectations can lead to problems in people's inner worlds. These individuals, who exhibit behaviors contrary to the religious and spiritual values in which they believe, begin to question themselves over time. The use of religious stories is important for dealing with this conflict that has emerged between one's spiritual world and social life and for determining the points that are clogged within the family system (Malik, 2018). In this way, the impact of religious stories is benefitted from while discovering the meaning of life within the family system. How discovering the meaning is provided in the therapy is explained by using the technique of benefitting from the religious stories in the section of the book Malik (2018) published. The use of this technique is described in Table 1 by benefitting from the case stated in the author's article.

\section{Spiritual Dialogue}

Spiritual dialogues are based on talking about the situations that extend beyond clients' selves and daily experiences. Using the spiritual dialogue technique within systemic work encourages the client and therapist to be curious, ask questions, and look beyond the self to consider the meaning of life. In systemic family therapy, spirituality encompasses the environment, God, and the person's inner world. By using this technique, it attempts to have the therapists' and clients' dreams related to change be embodied through scrutiny (Larner, 2017). 
Table 1.

A Case Regarding The Use of Religious Stories Using the Example from Malik (2018).

Selime, who applied for counseling due to the relational problem she has with her son Shadid, has a 23-year-old daughter and the 21-year-old son. The family is of Pakistani origin but grew up in England. Selime stated she had just ended her 25-year marriage due to her spouse's mental health problems. Although the children see their father, their relationship with him is quite limited. The basic problem Selime is experiencing with Shadid is that he is unemployed and she suspects he is using cannabis. This issue has caused repeated arguments between the mother and the child. Upon learning of the situation, Selime and Shadid were called to the therapy together. In the next meeting, Shadid stated he had been a musician for some time and had a music group that would begin recording soon. He also confirmed that he used cannabis from time to time with his group of friends. According to Shadid, however, the real problem was that his mom was oppressing him because music is considered haram in Islam. He stated that, unable to withstand the pressure from his mom, he had later left the group in order to please her. Shadid began showing symptoms of depression when the band continued on its way successfully. He also increased his cannabis use in this period. When Shadid, whose depressive state continued for a while, became interested in photography, he also gave up that interest as his mother stated that photography is haram. Shadid stated that his mood was completely depressed currently and that his relationship with his mother was very broken. The therapist conducted studies with the family on communication structures for a while. After Selime left her husband, Shadid was seen to take on the role of the only man in the house and to begin generalizing some expectations in this framework. Along with the family system that had gone to pieces on Shadid, new duties and responsibilities had been forced on him. The therapist began seeing Selime and Shadid separately from time to time in the following sessions. During one session, Shadid expressed to the therapist that he thought he couldn't be a good son unless he submits to his mother to the degree to which Ismael had submitted to Abraham in the Qur'an. From this point on, the therapist began focusing on the stories in the Qur'an and the meanings they reveal. The therapist searched for a relevant meaning with Shadid through Abraham's characteristics of fatherhood, what kind of relationship Abraham and Ismael had, and what kind of a relationship they had with Allah (swt). Assessments were made over the meaning of the relationship with his mother in terms of Ismail's sacrifice. The sacrifices he made for his mother were emphasized in the continuation of the therapeutic relationship. Shadid, realizing he had not done research on whether music and photography were haram, began searching for proper information by researching the topic. He acknowledged that cannabis use is forbidden and that it impacts his future life.

In the later sessions, the therapist, taking the family together, emphasized the meanings obtained from this story and the concept of obedience that the mother expects from her son. During the interviews, Selime, while stating that she had not doubt the drug use was forbidden and that she also found the music and lifestyle that formed together with this use meaningless, admitted that she wasn't so sure about photography. Selime was discovered to see the separation from her husband as a loss underlay her desire to keep Shadid under constant control and her perception that she feared losing him. While working on her anxiety, Selime talked about how she had been raised by her father and stepmother. Selime here is understood to also have deeper losses. At the end of the process, the problems within the family system had been fixed by reworking Selime's expectations in accordance with the commands from Allah. This is because Selime had in fact been using her own expectations as if they were Allah's. Selime in fact wanted her son's interest in photography to not be harmful, but he needed to change his cannabis use and the lifestyle that occurred around it.

In most of the therapies conducted with Muslim families, parents are seen to reflect their views onto God and in this way create a focus of social control. The use of religious stories in therapy is an important method in enabling sessions that will be performed for understanding them, the meanings that will be extracted, and the discovery of these types of impediments within the family system. The experiences of the Prophet, the experiences of his companions, and stories included in Sufi works like Rumi and Yunus Emre can be benefitted from while applying the technique. Kakar (1992) states that legends, myths, and stories feed from a common cultural consciousness. These texts are a rich source of psychological information. They can help us organize the experiences we have with our inner world with the outer world by impacting our emotions and thoughts.

When considering Bateson's (1979) studies on systemic family therapy, every systemic dialogue can be assumed to evoke some spiritual things. In this context, systemic family therapy forms a spiritual therapeutic field because in this school of thought the client is encouraged to ponder over the world, over the self, and over the other patterns that connect the person to life. This is what precisely exists at the center of the practices systemic family therapists perform. In other words, being systemic also naturally means focusing on spirituality. 
The healing power of a therapeutic dialogue comes from the empathy, trust, and sense of love that is housed within it. The spiritual dialogue technique used in systemic family therapy also gets its power from here. Larner's (2017) article discusses how spiritual dialogue can be used in therapy session made with youths experiencing existential despair who are depressed and suicidal. The use of this technique is described in Table 2 by benefitting from the case mentioned in the author's article.

Table 2.

Describing the Use of Spiritual Dialogue Using a Case Study (Larner, 2017)

13-year-old David applied to therapy together with his mother with the complaint that he had harmful behaviors toward himself and his surroundings due to the emotional problems he experiences. To the questions in the first interview related to the content of the harmful behavior, he said he had tried to jump in front of a bus to kill himself but he couldn't make this happen because a friend had intervened. David, who had recently learned that he had lost his father and grandmother, experienced an emotional catharsis by crying at the first interview. The therapist commented that he had attempted suicide due to the impact of still being unable to get through the mourning process. Alongside all these, David stated that he occasionally injured his arms with scissors and often made plans to jump off the school's balcony. When the therapist asked whether or not he had shared this with his mother when he feels this way, David stated that he did not share with her because he didn't want to worry her.

Upon David's declarations, the therapist formed a security plan with David. He was interviewed on the issue of what would be able to prevent him if he feels he will again attempt suicide. The day after this interview, the mother called the therapist, saying David had cut his arms with a pair of scissors. The therapist wanted to have a few individual sessions with David regarding this. These sessions went to the root of David's behaviors. David stated that, despite losing his father three years ago, he still couldn't get over the mourning process, and his emotional problems became stronger at Christmas and on his birthday in particular. After discussing the steps of the grieving process, the therapist asked David, "What are the reasons for living?" to which David gave answers such as, "Going on holidays with my mom. Going to church. Being Christian." After the interview, David, who accepted that he was angry with God for ultimately having taken his father from him and who showed this anger by harming himself and his surroundings, was directed to an internal questioning using Socratic methods. His views on God were discussed. At the end of the process the spiritual inquiry continued for David, who had ended his suicidal thoughts with the decision that leaving the world through suicide would just be leaving his memories of his father. The therapist drew David's attention to a new point by asking questions about what benefits being Christian had provided in coping with mourning up to this time. David stated that when he prayed for preserving the memories of his father, God was helpful at being able to access these memories when he wished. An in-depth dialogue was entered on this topic; as a result, David judged that he could continue his life without mourning. The therapist realized that spiritual experiences had had a big impact on David making this judgment.

In the session two weeks later, David came to therapy stating that his life was getting better. He stated that his belief in God had helped him a lot in the mourning process and that he would be able to continue his life without these feelings anymore. Thanks to his belief in God, David ended the grieving process related to his father without succumbing to depression or suicidal phenomena; he now began to focus on his memories about his father. At the end of the process, discussions were held with David about his responsibilities at school and how to be able to handle stress. In the control interviews made a month after the end of the process, everything was seen to be on its way for David and his thoughts on harming himself and on suicide had been eliminated.

\section{Results}

Therapists working to integrate spirituality into family therapies in the late 20th century brought new concepts and information to the literature by performing much research on the areas of spiritually oriented family therapies thanks to the changing paradigm together with the 21 st century. Systemic family counseling theory also comes at the top of the family counseling theories that have been researched on the issue of spirituality. The purpose in spiritually oriented systemic family therapy is to 
provide the use of spirituality as a tool while creating harmony and balance among the systems. In order for a therapist who adopts the systematic approach to be able to touch upon spirituality during the session, the client needs to consider their views on this concept. Aside from the therapist fostering themselves on the issue of spirituality, the client also must approve of including spirituality into the session. After providing these conditions, the therapist plans the sessions by determining the points within the family system where the concept of spirituality contacts.

By discovering the communication judgments and distorted relationships that have been molded into the family system, a good family therapist should be able to use spirituality in resolving these relationships and communications. The effective use of the spiritual dialogue technique can be beneficial by creating new communication patterns due to spirituality. In this way, family members' being more productive in terms of developing alternative relationships can be enabled by increasing their awareness.

Therapists should plan the sessions and process by taking into account clients' approaches to the concept of spirituality. Clients should be allowed to decide whether or not to include spirituality in the process by taking their thoughts on this concept into consideration. While doing this, asking appropriate questions and exploring the client's inner world comes at the top of systemic therapists' most frequently used methods. When clients' approaches to spirituality are detected in a sound manner during the therapeutic relationship process, the therapist's work gets much easier. Therapists can actively use it among their coping skills by revealing the power of spirituality and the healing power of social relationships that can be established in the spiritual environment during the sessions.

A large portion of the scientific research made on spiritually oriented systemic family therapy and discussed in this section is research that has been performed outside of Turkey. The concept of spirituality has started to gain importance in the psychology literature together with the changing paradigm. Many studies related to the concept of spirituality are known to have been done in the field of positive psychology in particular. When examining the literature, studies related to the use of spirituality in systemic family counseling are seen to be limited both abroad as well as in Turkey. Through the research made in the last century, the concept of spirituality, whose effect has emerged in human life, is believed to assume a role that supports individuals in the family counseling process. Through this study, pioneering the research done on the effect of spirituality in family systems is aimed by drawing the attention of the researchers and therapists who work on systemic family therapy in Turkey to the subject. Converting the cases where family counselors interested in the subject have worked into publications in the form of case reports and having academicians who perform research on family issues give importance to the related field may be useful in terms of filling in the deficiency in the literature. 


\section{Acknowledgement}

This article does not involve any human participant data, and thus no ethical approval was required.

\section{Resources}

Bateson, G. (1979). Mind and nature: A necessary unity. Toronto, Canada: Bantam Books.

Bentheim, S. (2005). Couple congruence and spirituality: Expanding Satir's model through seven couple narratives. Doctoral dissertation, University of Victoria, Canada.

Bowen, M. (1978). Family therapy in clinical practice. New York, NY: Jason Aronson Book.

Carlson, T., Fitzpatrick, D., Hecker, L., \& Killmer, J. M. (2002). Religion, spirituality, and marriage and family therapy: A study of family therapists' beliefs about the appropriateness of addressing religious and spiritual issues in therapy. The American Journal of Family Therapy, 30, 157-171.

Dallos, R., \& Draper, R. (2010). An introduction to family therapy systemic theory and practice (3rd ed.). London, UK: McGraw Hill Open University Press.

D'Souza, R., \& Rodrigo, A. (2004). Spiritually augmented cognitive behavioural therapy. Australasian Psychiatry, 12(2), 148-152.

Duba, J. D., \& Watts, R. E. (2009). Therapy with religious couples. Journal of Clinical Psychology, 65(2), 210-223.

Frame, M. W. (2003). Integrating religion and spirituality into counseling: A comprehensive approach. Pacific Grove, CA: Brooks/Cole Publishing Company.

Goldenberg, I., \& Goldrberg, H. (1991). Family therapy an overview. Pacific Grove, CA: Brooks/ Cole Publishing Company.

Griffith, B. A., \& Rotter, J. C. (1999). Families and spirituality: Therapists as facilitators. The Family Journal, 7(2), 161-164.

Hedges, F. (2005). An introduction to systemic therapy with individuals: A social constructionist approach. New York, NY: Palgrave Macmillan.

Helmeke, K. B., \& Bischof, G. H. (2007) Couple therapy and spirituality and religion. Journalof Couple \& Relationship Therapy, 6(1), 2, 167-179.

Horozcu, Ü. (2010). Tecrübî araştırmalar işığında dindarlık ve maneviyat ile ruhsal ve bedensel sağlık arasındaki ilişki. Milel ve Nihal, 7(1), 209-240.

Kakar, S. (1992). The analyst and the mystic: Psychoanalytic reflections on religion and mysticism. Chicago, IL: University of Chicago Press.

Kerr, M., \& Bowen, M. (1988). Family evaluation: An approach based on Bowen Theory. New York, NY: W. W. Norton \& Company.

Kesici, Ş., Bayrakc1, E., Mert, A., \& Kiper, C. (2013) Vaka örnekleriyle birlikte aile danışma kuramlarl ve teknikleri. Ankara, Turkey: Nobel Yayınları.

Krause, I.-B. (2002). Culture and system in famıly therapy. New York, NY: Karnac.

Krok, D. (2008) The Role of spirituality in coping: Examining the relationships between spiritual dimensions and coping styles. Mental Health, Religion, and Culture, 11, 643-653.

Larner, G. (2017). Spiritual dialogues in family therapy. Australian and New Zealand Journal of Family Therapy, 38, 125-141. 
Malik, R. (2018). Islamically integrated psychotherapy. In C. York Al-Karam (Ed.), Family therapy and the use of Qur'anic stories (pp. 152-172). West Conshohocken: Templeton Press.

Mert, A. (2014). Sistemik aile yönelimli psiko-eğitim programının değerler, algılanan sosyal destek ve çift uyumuna etkisi. Doctoral dissertation, Sakarya Üniversitesi Eğitim Bilimleri Enstitüsü.

Minuchin, S. (1974). Families and family therapy. Cambridge, MA: Harvard University Press.

Minuchin, S., Rosman, B. L., \& Baker, L. (1978). Psychosomatic families: Anorexia nervosa in context. Cambridge, MA: Harvard University Press.

Nichols, M. P., \& Schwartz, R. C. (2004). Family therapy concepts and methods (6th ed.). Upper Saddle River, NJ: Pearson Education.

Özabacı, N., \& Erkan, Z. (2013). Aile danışmanlığı kuram ve uygulamalara genel bir bakış. Ankara, Turkey: Pegem Yayınları.

Pargament, K. I. (2002). The bitter and the sweet: An evaluation of the costs and benefits of religiousness. Psychological Inquiry, 13(3), 168-181

Pargament, K. I. (2007). Spiritually integrated psychotherapy understanding and addressing the sacred. New York, NY: The Gullford Press.

Polanski, P. J. (2003). Spirituality in supervision. Counseling and Values, 47, 131-141.

Sperry, L., \& Mansager, E. (2007). The relationship between psychology and spirituality: An initial taxonomy for spiritually oriented counseling and psychotherapy. Journal of Individual Psychology, 63(4). 359-370.

Storms, L. E. (2011). Milan systemic family therapy. In L. Metcalf (Ed.), Marriage and family therapy a practice-oriented approach (pp. 201-227). New York, NY: Springer Publishing Company.

Swinton, J. (2001). Spirituality and mental health care: Rediscovering a 'forgotten' dimension. London, UK: Jessica Kingsley Publishers.

Turkish Language Institute. (2019). Retrieved from https://sozluk.gov.tr/

Walsh, J., \& Harrigan, M. (2003). The termination stage in Bowen's family systems theory. Clinical Social Work Journal, 31(4), 383-394.

Worthington E. L., \& Aten, J. D. (2009). Psychotherapy with religious and spiritual clients: An introduction. Journal of Clinical Psychology, 65(2), 123-130. 